\title{
Cerebrotendinous xanthomatosis: a rare cause of spinocerebellar syndrome
}

\section{Żółtakowatość mózgowo-ściegnista: rzadka przyczyna zespołu rdzeniowo-móżdżkowego}

\author{
Monika Ostrowska', Krzysztof Banaszkiewicz', Anna Kiławiec', Teresa Róg', Dieter Lütjohann², Andrzej Szczudlik \\ 'Department of Neurology, Jagiellonian University Medical College, Krakow, Poland \\ 2Institute of Clinical Chemistry and Clinical Pharmacology, University Clinics of Bonn, Bonn, Germany
}

Neurologia i Neurochirurgia Polska 2011; 45, 6: 600-603

\begin{abstract}
A 34-year-old patient demonstrating pyramidal and cerebellar signs, accompanied by epilepsy, peripheral neuropathy, mental retardation and bilateral cataract was diagnosed with cerebrotendinous xanthomatosis based on the clinical picture, magnetic resonance imaging of the brain and serum sterol analysis. Tendon xanthomas were not observed in this case. After establishing the diagnosis, treatment with chenodeoxycholic acid and statin was introduced. During the next two years of the follow-up, serum cholestanol and $7 \alpha$-hydroxycholesterol levels decreased in response to the therapy, but this was not reflected in the patient's neurological condition, which was slowly progressing. Treatment effectiveness in cerebrotendinous xanthomatosis is variable, notably better in patients who had started therapy before the injury to the nervous system took place. The present case report points to cerebrotendinous xanthomatosis as a rare cause of spinocerebellar syndrome, which might be treatable if diagnosed in early life.
\end{abstract}

Key words: cerebrotendinous xanthomatosis, spinocerebellar syndrome, treatment.

\section{Introduction}

Cerebrotendinous xanthomatosis (CTX) is an autosomal recessive lipid storage disorder caused by deficiency in a mitochondrial enzyme - 27-sterol hydroxylase (CYP 27), which is involved in the conversion of cholesterol into bile acids. Impairment of this metabolic path-

\section{Streszczenie}

U 34-letniego chorego z objawami piramidowymi i móżdż kowymi, padaczką, neuropatią obwodową, upośledzeniem umysłowym oraz obustronną zaćmą na podstawie obrazu klinicznego, badania rezonansu magnetycznego mózgu i oznaczenia stężenia steroli w surowicy rozpoznano zółtakowatość mózgowo-ścięgnistą. Nie obserwowano u tego chorego żółtaków ścięgien. Do leczenia włączono kwas chenodeoksycholowy oraz statynę. Chociaż podczas kolejnych dwóch lat obserwacji stwierdzono zmniejszenie stężenia cholestanolu i $7 \alpha$-hydroksycholesterolu w surowicy chorego w odpowiedzi na leczenie, jego stan neurologiczny stopniowo się pogarszał. Odpowiedź na leczenie żółtakowatości mózgowo-ścięgnistej jest zróżnicowana; lepsza u chorych, u których leczenie rozpoczęto, zanim wystąpiły zmiany w ośrodkowym układzie nerwowym. Przedstawiany opis przypadku zwraca uwagę na żółtakowatość mózgowo-ścięgnistą jako rzadką przyczynę zespołu rdzeniowo-móżdżkowego, który mógłby być uleczalny, jeśli zostałby rozpoznany na wczesnym etapie życia.

Słowa kluczowe: żółtakowatość mózgowo-ścięgnista, zespół rdzeniowo-móżdżkowy, leczenie.

way leads to excessive formation of cholestanol, a poorly soluble compound that later accumulates in the tissues, predominantly in the brain, tendons, lenses and lungs [1].

Clinical manifestations of CTX include progressive neurological dysfunction (pyramidal and cerebellar signs, epilepsy, mental retardation, extrapyramidal features, polyneuropathy), bilateral cataract, tendon xanthomas, and

Correspondence address: dr Monika Ostrowska, Katedra i Klinika Neurologii CM UJ, ul. Botaniczna 3, 31-503 Kraków, e-mail: mostroff@interia.pl Received: 13.01.2011; accepted: 24.05.2011 
diarrhoea. Due to varying occurrence of these signs and symptoms, the diagnosis may not be straightforward. Cerebrotendinous xanthomatosis is potentially treatable. Administration of chenodeoxycholic acid inhibits the synthesis of cholestanol and bile alcohols and thus can stop the progression of clinical symptoms. However, treatment is most efficient if started at early stages, before irreversible brain lesions take place.

We describe a patient with spinocerebellar ataxia as the major symptom, who was diagnosed with CTX. The patient has been treated with chenodeoxycholic acid and statin, but his condition failed to improve during twoyear follow-up.

\section{Case report}

A 34-year-old male was admitted with progressive gait impairment and concomitant slurred speech, that had been present for several months. There were behavioural problems reported by the patient's family: he became more impulsive, irritable and had lost his interests during the preceding months. His medical history also revealed bilateral cataract developed in his childhood, mild mental retardation and epilepsy, which started when he was 17 . The family history was not remarkable.

Neurological examination on admission revealed spastic paraparesis with bilateral extensor plantar responses, cerebellar ataxia, pes cavus and slight, predominantly distal wasting of lower limbs. The tendons were not enlarged. The patient's score on the Mini-Mental State Examination (MMSE) was 24. Neuropsychological assessment indicated frontal and subcortical dysfunction.

Electroencephalography demonstrated slight slowing of background rhythm and groups of delta waves in centro-parietal leads. Nerve conduction study and electromyography were suggestive of chronic, primary demyelinating, sensorimotor polyneuropathy.

Magnetic resonance imaging (MRI) of the brain revealed hyperintense areas in $\mathrm{T} 2$-weighted images and FLAIR sequences in periventricular white matter and dorsal parts of the centrum semiovale, along corticospinal tracts in posterior limbs of the internal capsules, cerebral peduncles, pons, anterior part of the medulla oblongata and in dentate nuclei bilaterally, where they were accompanied by fluid signal areas. None of those areas showed contrast enhancement (Fig. 1).

Differential diagnosis in this case included autosomal dominant spinocerebellar ataxias, Marinesco-Sjögren syndrome, Friedreich's ataxia, mitochondrial diseases, abetalipoproteinaemia, multiple sclerosis (MS), leukodystrophy and CTX. The diagnosis of autosomal dominant spinocerebellar ataxia was questionable due to negative family history and hyperintensities on MRI. Nevertheless, genetic tests for spinocerebellar ataxia type 1,2 and 3 were performed and were negative. Magnetic resonance imaging findings were incompatible with the diagnosis
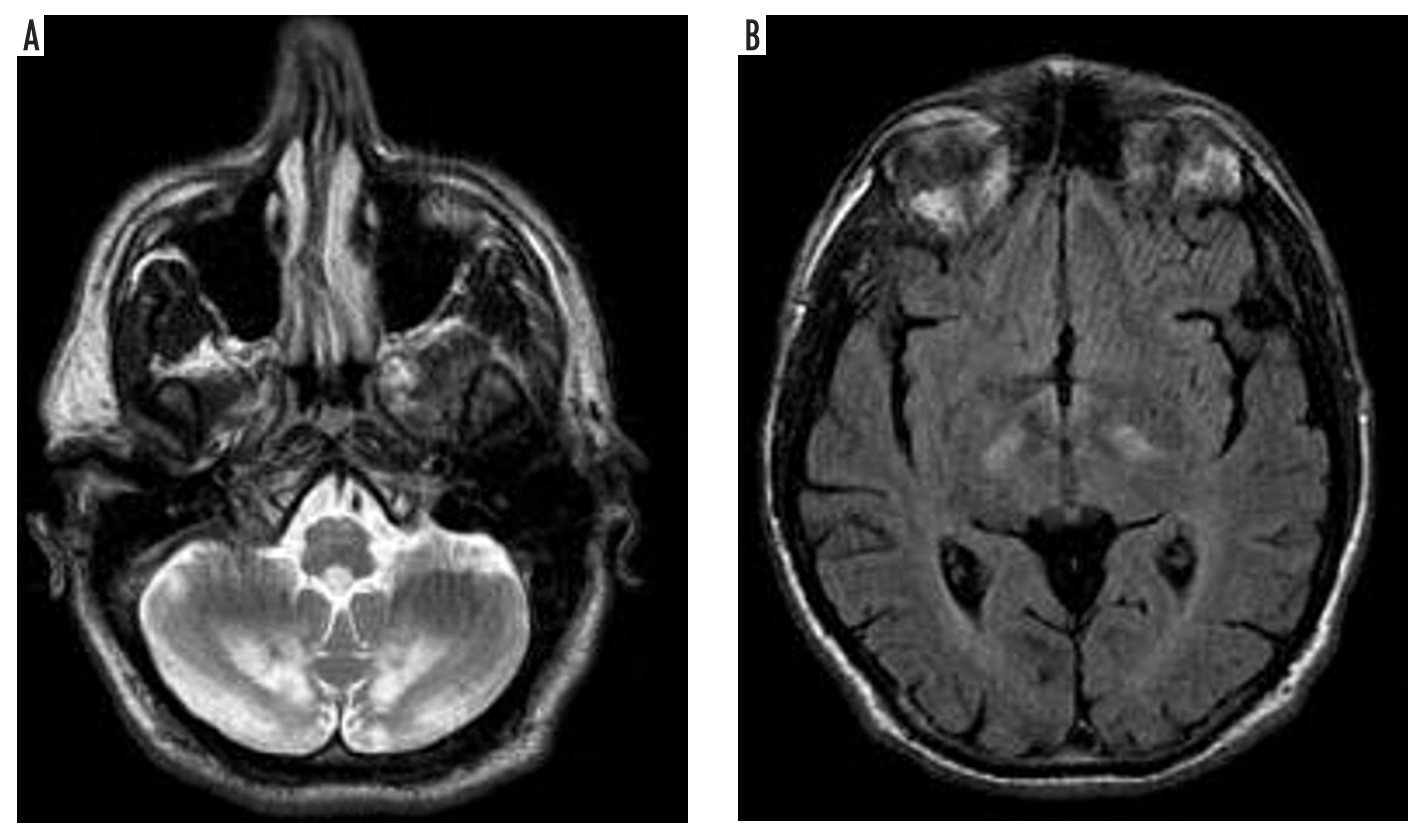

Fig. 1. Hyperintense areas in dentate nuclei of cerebellum bilaterally on axial T2-weighted magnetic resonance imaging (A) and in posterior limbs of both internal capsules on FlAIR sequences (B) 
of Marinesco-Sjögren syndrome or Friedreich's ataxia, as in these conditions neuroimaging demonstrates cerebellar atrophy only or is fairly normal. Serum and cerebrospinal fluid (CSF) lactate concentration was measured regarding possible mitochondrial disease; it was slightly increased in the serum and normal in CSF. Total serum cholesterol was insignificantly increased whereas LDL, HDL and triglycerides were normal. These findings allowed abetalipoproteinaemia to be excluded. Cerebrospinal fluid analysis revealed increased protein concentration $(77 \mathrm{mg} / \mathrm{dL}$; normal values $20-60 \mathrm{mg} / \mathrm{dL}$ ), but no intrathecal protein synthesis or oligoclonal bands. These results, not typical for multiple sclerosis, in combination with MRI and the clinical picture which covered additional features (juvenile cataracts, polyneuropathy), made the diagnosis of MS unlikely. White matter involvement was not diffuse, as in metachromatic leukodystrophy. The diagnosis of adrenoleukodystrophy was not probable either, as there were no signs of adrenal insufficiency and no evidence for X-linked inheritance. However, investigation of serum very-long-chain fatty acid levels was not performed.

Neurological signs and symptoms occurring in this case, accompanied by premature bilateral cataracts, together with brain MRI, led to the suspicion of CTX.

The analysis of the patient's serum sterols and oxysterols, performed in the Institute of Clinical Chemistry and Pharmacology, University of Bonn, revealed an increased level of cholestanol (3-4 times the upper limit), loss of 27-hydroxycholesterol and elevated $7 \alpha$-hydro xycholesterol (10 times the upper limit) in the serum. These results in combination with clinical syndrome and MRI findings allowed us to establish the diagnosis of CTX.

Treatment with $1000 \mathrm{mg}$ of chenodeoxycholic acid (CDCA) and $10 \mathrm{mg}$ of simvastatin was introduced and the patient was referred to the outpatient clinic for further follow-up. Control analysis of serum sterols was performed after six months of CDCA treatment and showed a decrease in $7 \alpha$-hydroxycholesterol and cholestanol levels, although the latter was still beyond the normal upper limit. In subsequent analyses there was further reduction of $7 \alpha$-hydroxycholesterol level, while cholestanol level continued to be slightly increased. Despite treatment, the patient's neurological condition slowly worsened during the following months. Balance impairment aggravated and falls occurred. Speech disturbances exacerbated and the patient began to have difficulty with swallowing. On neurological examination performed after two years of treatment there was progression of cerebellar and pyramidal signs with dysarthria, four-limb ataxia, adiadochokinesis, trunk asynergy, triparesis and a wide-based gait requiring assistance with walking. There was no significant cognitive decline. The patient has also developed extrapyramidal features, namely hypomimic face and general bradykinesia. The brain MRI was repeated twice during two-year follow-up and it did not demonstrate any changes in comparison to the first imaging.

\section{Discussion}

We describe a patient demonstrating a complex neurological syndrome with predominating cerebellar and pyramidal signs, accompanied by epilepsy, mental retardation, extrapyramidal signs, peripheral neuropathy and premature bilateral cataracts. The patient was diagnosed with CTX based on clinical grounds, brain MRI results and serum cholestanol analysis.

Cerebrotendinous xanthomatosis is a rare neurometabolic disease. There have been more than 200 cases reported in the literature so far [1]. The disease often begins in childhood with epilepsy, mental retardation, cataract and chronic diarrhoea. Progressive neurological syndrome with cerebellar ataxia, spastic paraparesis, polyneuropathy, cognitive impairment, psychiatric disturbances and extrapyramidal symptoms occurs at adolescent or young adult age [2]. Tendon xanthomas, typically detectable on Achilles tendons, are characteristic for CTX. Nevertheless, reports of CTX patients who have no tendon xanthomas, like the patient described above, have been published [3-5]. The presence of tendon xanthomas is not obligatory for the diagnosis of CTX, as they have been found to occur in $40 \%$ to $70 \%$ of patients $[1,6,7]$. However, absence of tendon xanthomas makes CTX not a diagnosis of choice and prolongs the diagnostic process.

The occurrence of the remaining signs is also variable. A retrospective analysis of 32 CTX patients revealed the presence of pyramidal signs in $81 \%$ of them, cerebellar ataxia in $56 \%$, low intelligence in $66 \%$, polyneuropathy in $31 \%$, epilepsy in $16 \%$ and extrapyramidal signs in $3 \%$. Diarrhoea, another major symptom of CTX which was not reported by the presented patient, was noted in half of the patients from the analysed group. The most consistent finding in this population was cataracts, appearing in $97 \%$ of patients [6].

Neuroradiological abnormalities in the presented case were suggestive of CTX. Brain MRI in CTX demonstrates bilateral hyperintensities of the dentate nuclei on T2-weighted images, as the most typical finding [8]. Other neuroradiological abnormalities include enhanced 
signal along the corticospinal tracts and in the topography of basal ganglia [9].

The diagnosis of CTX is confirmed by biochemical investigations that reveal increased cholestanol and bile alcohol concentrations and lack of 27-hydroxycholesterol in serum, as in the described case. Concomitant findings include increased urinary excretion of bile alcohols and reduced concentration of cholic and chenodeoxycholic acid in the bile [10]. Additionally, the diagnosis may be supported by demonstrating mutation in CYP27A1.

Cerebrotendinous xanthomatosis is considered to be a treatable disease. Administration of chenodeoxycholic acid, causing suppression of cholestanol and bile alcohol synthesis, is the most beneficial approach. Other therapeutic approaches include statin administration and LDL aphaeresis. Rarity of the disease makes it difficult to properly assess treatment efficacy, as most reports on treatment of CTX refer to single cases or small series only, except for one series of 17 patients described by Berginer et al. [11] and another series of 20 Dutch patients [12]. In some patients treated with CDCA, there was no further neurological progression or even reversal of the symptoms [5,11], whereas in others there was no improvement of the neurological condition $[4,12,13]$. As reported by Dotti et al., combined treatment with CDCA, LDL-aphaeresis and simvastatin significantly reduced serum cholestanol level in a CTX patient, but it was not followed by clinical improvement [13], similarly to the present case. One reason for therapy failure may be its delayed initiation, especially when the treatment is started after neurological signs have already emerged. In two adult males, in whom CDCA treatment was started after they had developed signs of CTX, there was only moderate clinical improvement, whereas their two nieces diagnosed and treated at the preclinical stage remained asymptomatic during 14 years of follow-up [14]

The present case points to a rare but potentially treatable cause of cerebellar and pyramidal syndrome. Cerebrotendinous xanthomatosis should be taken into consideration particularly when neurological syndrome is accompanied by bilateral cataract, tendon tumours or diarrhoea, although presence of all of these four features is not obligatory for the diagnosis. Treatment effectiveness highly depends on its initiation time.

\section{Acknowledgements}

We would like to thank Dr Christoph Clemen from the Center for Biochemistry, Medical Faculty, University of Cologne for his constructive opinion.

\section{Disclosure}

Authors report no conflict of interest.

\section{References}

1. Moghadasian M.H. Cerebrotendinous xanthomatosis: clinical course, genotypes and metabolic backgrounds. Clin Invest Med 2004; 27: 42-50.

2. Sedel F., Tourbah A., Fontaine B., et al. Leukoencephalopathies associated with inborn errors of metabolism in adults. $J$ Inherit Metab Dis 2008; 31: 295-307.

3. Siebner H.R., Berndt S., Conrad B. Cerebrotendinous xanthomatosis without tendon xanthomas mimicking MarinescoSjoegren syndrome: a case report. J Neurol Neurosurg Psychiatry 1996; 60: 582-585.

4. Pilo de la Fuente B., Ruiz I., Lopez de Munain A., et al. Cerebrotendinous xanthomatosis: neuropathological findings. J Neurol 2008; 25 5: 839-842.

5. Clemen C.S., Spottke E.A., Lütjohann D., et al. Cerebrotendinous xanthomatosis: a treatable ataxia. Neurology 2005; 64: 1476.

6. Verrips A., van Engelen B.G., Wevers R.A., et al. Presence of diarrhea and absence of tendon xanthomas in patients with cerebrotendinous xanthomatosis. Arch Neurol 2000; 57: 520-524.

7. Verrips A., Hoefsloot L.H., Steenbergen G.C., et al. Clinical and molecular genetic characteristics of patients with cerebrotendinous xanthomatosis. Brain 2000; 123: 908-919.

8. De Stefano N., Dotti M.T., Mortilla M., et al. Magnetic resonance imaging and spectroscopic changes in brains of patients with cerebrotendinous xanthomatosis. Brain 2001; 124: 121-131.

9. Barkhof F., Verrips A., Wesseling P., et al. Cerebrotendinous xanthomatosis: the spectrum of imaging findings and the correlation with neuropathologic findings. Radiology 2000; 217: 869-876.

10. Koopman B.J., Wolthers B.G., van der Molen J.C., et al. Cerebrotendinous xanthomatosis: a review of biochemical findings of the patient population in The Netherlands. J Inherit Metab Dis 1988; 11: 56-75.

11. Berginer V.M., Salen G., Shefer S. Long-term treatment of cerebrotendinous xanthomatosis with chenodeoxycholic acid. $N$ Engl J Med 1984; 311: 1649-1652.

12. Waterreus R.J., Koopman B.J., Wolthers B.G., et al. Cerebrotendinous xanthomatosis (CTX): a clinical survey of the patient population in The Netherlands. Clin Neurol Neurosurg 1987; 89: $169-175$.

13. Dotti M.T., Luetjohann D., von Bergmann K., et al. Normalisation of serum cholestanol concentration in a patient with cerebrotendinous xanthomatosis by combined treatment with chenodeoxycholic acid, simvastatin and LDH apheresis. Neurol Sci 2004; 25: 185-191.

14. Berginer V.M., Gross B., Morad K., et al. Chronic diarrhea and juvenile cataracts: think cerebrotendinous xanthomatosis and treat. Pediatrics 2009; 123: 143-147. 